Article

\title{
Insuring Water Supply in Irrigated Agriculture: A Proposal for Hydrological Drought Index-Based Insurance in Spain
}

\section{Dolores Guerrero-Baena * and José A. Gómez-Limón ${ }^{(\mathbb{D}}$}

Water Environmental and Agricultural Resources Economics (WEARE) Research Group, Faculty of Law and Business Sciences, University of Córdoba, Puerta Nueva s/n, E-14071 Córdoba, Spain; jglimon@uco.es

* Correspondence: dolores.guerrero@uco.es; Tel.: +34-957-212-205

Received: 11 February 2019; Accepted: 2 April 2019; Published: 3 April 2019

\begin{abstract}
In Mediterranean-climate regions, irrigated agriculture is especially vulnerable to the risk of hydrological drought and irrigators are particularly concerned about its negative effects. During a hydrological drought episode, irrigators receive insufficient water to meet their crops' water needs, giving rise to the so-called 'water supply gap'. In such circumstances, agricultural production and irrigators' incomes are considerably reduced. In order to minimize the negative effects associated with water supply gaps, a new index-based drought insurance scheme for irrigation is proposed, linked to the variable 'stock of water available in reservoirs'. The proposal, although tailored to Spain, could be easily adapted to other countries or regions because the features of hydrological drought risk are similar worldwide. It is expected that the proposed scheme will improve drought risk management in irrigated agriculture, stabilizing irrigators' incomes and guaranteeing the sustainability of irrigated agriculture in the face of global change.
\end{abstract}

Keywords: drought risk; water supply risk; irrigation insurance; water use; Spain

\section{Introduction}

Agriculture is an economic activity exposed to multiple risks that can negatively influence farmers' income and wealth [1-3]. Particularly notable among all these agricultural risks are production and market risks: production risks such as hail, frost or drought reduce the quantity and/or quality of agricultural production, while market risks are related to potential increases in input prices and decreases in agricultural product prices.

In Mediterranean-climate agricultural regions, such as in Spain, production risks associated with climatological factors pose a more serious threat than market risks [3,4]. This is because this type of climate is characterized by a high frequency of extreme weather events (e.g., hail or heat waves) and by an irregular rainfall pattern, severely affecting agricultural production. Rainfall variability leads to sharp fluctuations in crop yields under rainfed conditions, where precipitations are the only source of water. This is not necessarily the case with irrigated agriculture, where the availability of irrigation water can solve problems related to meteorological drought (below-average rainfall). In fact, irrigation techniques have been developed worldwide as a strategy for both increasing agricultural production and reducing drought-related production risks. It is only when meteorological droughts last for a long time and become hydrological drought episodes (instream flows and reservoir levels below normal) that irrigated agriculture is affected: the availability of water for irrigation is reduced, and thus irrigators cannot fully meet all their crop water needs. This situation, the so-called 'water supply gap', entails notable losses of production and income for irrigation farmers. 
In recent years, the changing climate has generated growing concern among irrigators in Mediterranean regions about irrigation water reliability, and they are becoming increasingly aware of the consequences of water supply gaps. Negative predictions about rainfall (lower water availability) and temperatures (higher crop water needs) in these regions could even threaten the sustainability of irrigated agriculture [5]. Furthermore, other global changes, such as increasing pressure from economic activities (mainly industry and tourism), population growth, rising living standards and worsening pollution, are likely to exacerbate the vulnerability of many Mediterranean regions to water scarcity and drought [6,7]. In fact, several studies have found a widespread interest among irrigators in reducing the uncertainty associated with the high variability of their water allotments for irrigation. That interest is manifested in their willingness to pay to reduce the said uncertainty [8-10]. Therefore, there is an urgent need to design new risk-management instruments that could be implemented by irrigators to minimize the foreseen negative impacts of hydrological droughts on irrigated agricultural production [11,12]. Of all the risk management tools suggested to date, insurance has been highlighted as a particularly efficient economic instrument to cope with this risk [13], as it can protect irrigators against financial losses resulting from droughts. In this sense, insurance is viewed as a key instrument forming part of the policy-mix to be implemented in order to adapt irrigated agriculture to climate change; it improves the resilience of the irrigation sector, which is facing increasing uncertainty and vulnerability due to changing climate conditions and other relevant drivers [14]. However, although agricultural insurance is highly developed in first-world countries such as Spain $[4,15]$, the risk of water supply failure in irrigated agriculture is not covered because multiple factors hinder the development of hydrological drought insurance schemes.

Within this context, the main objective of this paper is to contribute to the debate on how to support irrigators in managing hydrological drought risk, by proposing a new insurance scheme for irrigated agriculture capable of overcoming the problems that currently make this risk uninsurable. This scheme is tailored to Spain, as it provides a particularly interesting case study. For this purpose, we exhaustively analyze the factors that currently limit the development of this type of insurance and review previous studies that have proposed insurance schemes to cope with hydrological drought risk. This has allowed us to propose a technically feasible and commercially viable index-based insurance scheme that relies on a variable measuring the stock of water in reservoirs. This scheme is best suited to highly inertial water supply systems, i.e., those with a large water storage capacity compared to annual inflows and annual water demands, as is the case with many basins in Mediterranean and semi-arid developed countries. In order to illustrate how the proposed drought index-based insurance could work in a real-world setting, this paper provides a quantitative example in the Guadalquivir River Basin (southern Spain).

Finally, it is also worth commenting that although the proposed insurance scheme is tailored to Spanish irrigators, the appeal of the developed proposal extends beyond this national scope. Indeed, most of the factors hindering the implementation of hydrological drought insurance for irrigated agriculture are universal, and the technical features of the suggested index-based scheme are applicable in many other countries.

\section{Hydrological Drought Insurance as an Instrument for Adaptation to Global Change}

\subsection{The Risk of Water Supply Gaps in Irrigated Agriculture}

As commented above, when faced with a 'water supply gap', irrigators cannot fully meet all their crop water needs because there is not enough irrigation water available in reservoirs and instream flows (hydrological drought episode). The consequences of these water supply gaps in irrigated agriculture can be categorized in three areas: economic (micro and macro), social and environmental. First, from an economic point of view, water supply gaps lessen farmers' income, since they have to choose their crop mixes depending on the availability of water, reducing the irrigated area and/or growing less water-intensive and less profitable crops. On a macroeconomic level, a water supply gap 
diminishes total agricultural production and value-added of the farming sector and the other related economic sectors, such as the food industry or the agricultural input sectors. In addition, since farmers tend to be risk averse [16], in situations of high uncertainty about the availability of water for irrigation, they tend to reduce the use of inputs [17] and make fewer investments [18]. Therefore, in these situations, economic decision-making by farmers is not efficient from a public welfare perspective.

Second, from a social point of view, water supply gaps in irrigated agriculture may cause a considerable decline in agricultural employment, considering that one hectare of irrigated land generates, on average, 3.8 times more employment than the equivalent rainfed area [19]. In some cases, recurrent water supply gaps may even lead to the abandonment of certain crops that are especially vulnerable to the risk of insufficient water supply, such as fruit groves, which are much more labor-intensive than annual crops.

Third, it is worth mentioning the environmental consequences of water supply gaps: when water allotments for irrigation are below normal, many farmers might illegally extract water resources (i.e., groundwater extractions beyond those legally allowed) to cover their unsatisfied water needs partially. This may aggravate the problems related to the overexploitation of aquifers and surface water bodies (rivers, lakes, etc.) [20,21].

Due to all the aforementioned negative consequences of water supply gaps in irrigated agriculture, it is obvious that uncertainty about the availability of water for irrigation constitutes a major production risk for irrigators in Mediterranean-climate agricultural regions (microeconomic impact). It also poses a problem to society as a whole, taking into account its macroeconomic, social and environmental impacts on social welfare [22]. Therefore, the implementation of proactive measures to adapt to global change in irrigated agriculture must be a priority, in order to effectively manage this climate risk and mitigate its wide-ranging negative impacts [23,24].

Like any other entrepreneur running a business, irrigators are responsible for managing the set of risks that they face. However, public administrations should support farmers' decision-making by establishing an integrated public-private framework (with public incentives) to promote the appropriate adoption of risk management instruments [25]. Adequate management of risks in irrigated agriculture helps stabilize farmers' annual income and also, as previously mentioned, has positive economic, social and environmental consequences for society as a whole.

The strategy traditionally implemented to minimize hydrological drought risk has been to build new water infrastructures such as reservoirs, in order to capture and store a greater amount of water, a strategy known as 'supply-side policy'. However, increasing demands for water and the economic and environmental difficulties involved in enlarging storage reservoirs have ultimately forced policy-makers to stop implementing this kind of supply-side measure. This situation is especially evident in many river basins in Mediterranean and semi-arid regions that are considered hydrologically 'closed' [26,27], where any new demand for water can only be met if the water rights of other users are reduced.

River basin closure is motivating the scientific community and policy-makers to explore new demand-side instruments to manage hydrological drought risk [28]. Among these measures, it is worth highlighting the modernization of irrigation systems, as well as the implementation of water markets, water banks, water option contracts and hydrological drought insurance [29-33]. Moreover, several drought indicators, such as the Standardized Precipitation Index (SPI) [34], the Standardized Precipitation Evapotranspiration Index (SPEI) [35], the Surface Water Supply Index (SWSI) [36] and the Joint Deficit Index for Droughts (JDI) [37], have been proposed; the aim is to calculate these indicators regularly in order to provide accurate information to stakeholders and decision-makers involved in drought management. Of all these demand-side instruments, the hydrological drought insurance has been the focus of very little analysis in the literature as a potential tool for managing hydrological drought risk in irrigated agriculture. Moreover, there are virtually no reports of this kind of insurance scheme having been implemented in a real-life setting. 
Despite this scarce analysis and lack of real-world experience, during the last decade the use of agricultural insurance has been promoted by international institutions such as the World Bank, the Organization for Economic Cooperation and Development (OECD) and the European Commission (EC) as a powerful instrument for managing the risks facing farmers, allowing them to transfer the risk of agricultural production to an insurance company [12,38,39]. In this regard, these institutions suggest that it is necessary to insure some risks that are not currently covered, such as the risk of water supply gaps in irrigated agriculture. Furthermore, it is acknowledged that public incentives should be provided in order to encourage the widespread adoption of agricultural insurance as a useful tool for risk management in the farming sector. Public incentives may make this instrument more financially attractive for farmers and for insurance companies. As mentioned above, this public support is justified because adequate risk management in agriculture contributes to enhancing social welfare, through the improvement of agricultural production and the reduction of negative social and environmental impacts.

In this sense, the primary objective of hydrological drought insurance for irrigation should be to guarantee a stable level of income to farmers when their water allotments are lower than their needs. This type of insurance would thus act as a buffer against the microeconomic effects of a water supply gap, reducing uncertainty and allowing farmers to adopt more efficient economic decisions. Moreover, it is worth noting that by achieving this primary objective, this kind of insurance scheme would have a positive effect on rural development since the macroeconomic and social impacts of hydrological drought would also be minimized.

\subsection{Factors Hindering the Development of Hydrological Drought Insurance for Irrigators}

There are many factors that can explain why hydrological drought insurance for irrigators has not been implemented in a real-life setting [33,40,41]. Some of these factors relate to information asymmetries between the insurer and the insured, which also affect other types of agricultural insurance schemes:

- The 'moral hazard' problem, which arises when the farmer, having taken out an insurance policy, may intentionally behave carelessly regarding the covered risks, with the insurer being unaware of that behavior [42]. This would be the case, for example, with an irrigator who has taken out a hydrological drought insurance policy and, in situations of water supply gaps, does not use his/her entire annual allotment to irrigate. Thus, the irrigator would save costs (lower irrigation costs) and, at the same time, would stand to receive a greater indemnity payment (higher losses claimed).

- The 'adverse selection' problem, that is, those farmers that are most likely to suffer losses are more willing to take out insurance. Since insurance premiums are usually set according to an average measure of risk, low-risk farmers will not be as motivated to insure their activities as high-risk farmers. In this way, a 'self-selection' process occurs where the insurance subscribers would be increasingly likely to suffer losses [43]. This problem creates an actuarial imbalance for the insurer (claim payments greater than premium charges), which inevitably leads to a progressive rise in insurance costs and, ultimately, to the inefficiency of the instrument $[44,45]$.

Both problems could be overcome in a drought insurance scheme for irrigated agriculture by applying the appropriate measures. To this end, it would be necessary to: (a) segment potential insurers (irrigators) according to their level of exposure to the risk of water supply gaps (e.g., dividing them into sub-basin levels) in order to apply premiums corresponding to the risk actually borne by each farmer; (b) implement bonus-malus incentive systems that individually correct the premiums based on farmers' historical behavior; (c) establish deductibles; and (d) apply evaluation rules that audit farmers' behavior in the event of a loss. In any case, it is worth noting that all these measures generate additional transaction costs that affect the cost of the premiums. 
Moreover, the design and implementation of hydrological drought insurance for irrigated agriculture present some specific problems that also need to be solved:

- Hydrological drought is a systemic risk [46], which implies that water supply gaps affect a large number of irrigators (all those located in the same river basin) at the same time. Thus, the indemnity payments may jeopardize the solvency of insurance companies. This issue could be addressed, on the one hand, through reinsurance and, on the other hand, by encouraging insurance companies to build up substantial capital reserves. Both measures would also increase the cost of the premiums.

- As already mentioned, climate models predict a decrease in the average volume of water available for irrigation and an increase in its variance, changes that would raise the cost of the premium in a hydrological drought insurance scheme. However, there is a high degree of uncertainty about future changes in the probability distribution function (PDF) characterizing the stochastic variable 'water allotments', which is key information for the insurance actuarial analysis [47]. This problem may be solved by adding an additional ambiguity load into the insurance premium [46].

- The existence of different sources of water supply for irrigation also generates a problem because hydrological droughts do not affect all of them equally. This would be the case, for example, with an irrigator who has rights to surface water, but can also access groundwater sources, reclaimed water and/or desalinated water. In a hydrological drought situation involving cuts in surface water allotments, the irrigator could offset the water supply gap by using any other water sources, such as desalinated water, which is totally secure (this resource is not exhaustible). Under this circumstance, the water supply gap would not be insurable, given the difficulty of complying with the indemnity principle: the insured farmer could benefit from the loss since the indemnity received may be higher than the extra cost incurred for using the other sources of water. Thus, it could be inferred that only those irrigators who have water rights for just one source of supply potentially subject to annual allotment constraints (i.e., a surface water right served by a river basin agency) should be able to take out a hydrological drought insurance policy.

- Farmers (potential insured parties) may influence the decision related to the amounts of water to be distributed among irrigators (water allotments) in each irrigation season. Indeed, irrigators are commonly represented in river basin agencies and take part in the decision-making process regarding the setting of annual water allotments, thus influencing the probability of loss occurrence. This issue makes the risk of a water supply gap uninsurable, since losses due to allotment cuts cannot be considered as entirely accidental.

- In many countries, spot water markets and water banks are allowed during drought periods [30,31]. Thus, the amount of water that irrigators actually use for irrigation in their own farms depends on their economic decisions: whether they decide to sell their water allotment or to buy additional water from other farmers. For this reason, hydrological drought insurance cannot protect against production (crop) losses due to a lack of water, because these losses could be aggravated if the farmer decides to sell his/her water allotment. Thus, a drought insurance scheme should insure the value of the farmer's water allotment, and not the value of his/her crop yield (as in most existing crop insurance schemes). If the insurance scheme is designed this way, irrigators could be protected against lost profits caused by failures in water supplies (reductions in water allotments), regardless of their actual use of water.

- In river basins where reservoirs have a large water storage capacity compared to annual inflows and annual water demands (i.e., inertial water supply systems), hydrological droughts only involve reductions in water allotments after extended periods of meteorological drought, normally longer than a year. In these river basins, it is very difficult to set an appropriate time frame for drought insurance. This is the case with the basins located in southern Spain [48], as well as in most of the basins in Mediterranean and semiarid developed countries. In these inertial systems, if the amount of water stored at the beginning of the hydrological year (in October, when reservoirs reach their lowest water levels after the dry summer) is 'normal' (similar to the average 
for this month), there is typically zero probability of a water supply gap in that hydrological year. Consequently, water needs for irrigation are certain to be fully met, even if the year is drier than average. Under this circumstance, no one would be willing to take out insurance covering the risk of cuts in water allotments that year. In these basins, cuts in water allotments would occur only after two or three years with rainfall significantly below the average. Thus, the lower the volume of water stored at the beginning of the hydrological year, the greater the probability of allotment cuts during the year and, therefore, the higher the willingness to take out a drought insurance policy. This calls into question the design of a single-year hydrological drought insurance scheme, similar to other agricultural insurance schemes, because the probability of loss occurrence in a given year is not a statistically independent phenomenon; the probability of a water supply gap differs depending on whether the hydrological year starts with stored water levels above or below the historical average. This fact points to the need for multi-year policies or specific contract conditions that encourage the renewal of policies year after year.

While these limiting factors pose a problem in the design and implementation of hydrological drought insurance for irrigation, some authors have begun to analyze how to effectively overcome them. Although the literature on this topic is scarce, several studies have made interesting proposals about how to address these factors. In the next section, we will review the most relevant contributions.

\section{Design Alternatives for Insuring Hydrological Drought Risk in Irrigated Agriculture}

There are several types of agricultural insurance schemes (see Table 1). A common classification is based on the risks covered [49]: (a) single-risk or single-peril insurance, for example, to cover the risk of production or income losses due to hail or frost; (b) combined or multiple-peril insurance, which protects against income losses due to several risks, such as hail, frost, and floods; (c) yield insurance, which covers any risk affecting crop yields (income), including all climatic and biological (pests) risks, as well as systemic risks not usually covered by single- or multiple-peril insurance (e.g., meteorological drought in rainfed agriculture); and (d) revenue insurance, covering any risk impacting yields (income losses) or prices (drops in output prices or rises in input prices) in order to guarantee a predefined revenue for insured farmers.

Table 1. Types of agricultural insurance schemes ${ }^{1}$.

\begin{tabular}{|c|c|}
\hline Classification Criteria & Types \\
\hline Risks covered & $\begin{array}{c}\text { Single risk or single-peril insurance } \\
\text { Combined or multiple-peril insurance } \\
\text { Yield insurance } \\
\text { Revenue insurance }\end{array}$ \\
\hline Evaluation of the damage & $\begin{array}{l}\text { On-field loss assessment insurance } \\
\text { Index-based insurance }\end{array}$ \\
\hline Role of public authorities & $\begin{array}{c}\text { Private insurance } \\
\text { Public-private insurance }\end{array}$ \\
\hline
\end{tabular}

Agricultural insurance can also be classified according to how the damages suffered in the farms are assessed: (a) on-field loss assessment insurance (commonly known as 'traditional insurance'); and (b) index-based insurance (see below). In this sense, it is worth highlighting the study by Ruiz et al. [48] who proposed an in-field income loss assessment insurance in Spain to cover the risk of hydrological drought in irrigated agriculture, very similar to the other agricultural insurance schemes available in this country. However, it should be pointed out that the use of this type of loss assessment for cases of systemic risks (such as water supply gaps) has been criticized because it is difficult and expensive to implement when a large number of assessments must be carried out by qualified experts at the same 
time [46]. Moreover, this scheme proposal fails to address most of the aforementioned issues related to hydrological drought insurance. In fact, the only problem explicitly mentioned is that of water trading, with the assumption that the implementation of this insurance scheme would involve the prohibition of any water transfers by the irrigators insured; this requirement would be difficult to enforce in a real-life setting because of the existence of informal water markets.

In index-based insurance schemes, damage assessment is carried out indirectly through a variable or 'index' strongly correlated with the contingency covered (income or yield losses), without the need for individual loss declarations and in-field assessments. For example, an insurance scheme to cover drought risk in rainfed agriculture could be based on a cumulative rainfall index. Different types of index-based insurance schemes include the following [50]:

- Yield or income index-based insurance, based on a direct measure, such as the average yields or incomes within the same agricultural region.

- Indirect index insurance, based on one or several variables exogenous to the farms. It is possible to differentiate between: i) climatic index insurance, which may consider variables such as rainfall or temperature; ii) agro-climatic index insurance, which takes into account indicators such as the humidity of the soil; iii) satellite imagery index insurance, for example, those relying on vegetation indexes; and iv) index insurance based on other variables, such as the amount of water stored in reservoirs or reservoir inflows.

Although traditional agricultural insurance (in-field assessment) is the most widespread worldwide, index-based insurance offers a series of advantages that considerably reduce the cost of the premiums $[38,46,51]$ :

- As indemnities are calculated according to the value of an objective and non-manipulable index, it is not necessary to perform in-field damage evaluations.

- Because the indexes used are non-manipulable, the farmers do not have any capacity to influence the result of the value of the index (and the indemnities) through their behavior. Thus, the moral hazard problem is negligible.

- There is a greater transparency in the calculation of indemnities in comparison with traditional insurance, so there is no room for arbitrariness, with conflict resolution costs consequently minimized.

- Moreover, as the information for the index (e.g., information on the variable rainfall) is the same for both parties, the insured and the insurer, adverse selection is less of a problem than with traditional insurance.

However, the major drawback of index-based insurance is 'basis risk'; that is, the risk related to possible differences between the indemnity (calculated according to the index) and the actual loss suffered by the farmer. It may happen that when a farmer experiences a loss on his/her farm, the indemnity payment, based on the exogenous index, is either far above or below the actual loss. This situation may occur if there is not a strong positive correlation between the index measured and the loss experienced. Accordingly, it is evident that the main condition that a variable must meet to be considered as an index is a high correlation with the insured loss, in order to reduce basis risk. Other relevant requirements of index-based insurance are the following [52]:

- The method used to calculate the indexed variable must be available to all potential insured farmers.

- The values to be used in the index must be objective and non-manipulable, and must be regularly made public through appropriate diffusion channels.

- There must be historical records of the exogenous variables used to calculate the index, and information regarding feasible future trends (climate models accounting for uncertainty about future changes in the PDF characterizing the stochastic variable 'water allotments') so that insurance companies can perform actuarial analyses based on the proposed index. 
The literature offers few proposals of index-based insurance schemes to cover the risk of hydrological drought in irrigated agriculture. In Australia, Zeuli and Skees [53] designed a rainfall index contract, compatible with transactions in a spot water market. However, the authors did not address the imperfect correlation between the rainfall variable used as the index and the risk of hydrological drought (actual farm losses).

For Mexican irrigators, Leiva and Skees [54] proposed a hydrological drought index-based insurance considering the variable 'inflow accumulation', also demonstrating that index-based insurance is fully compatible with water markets. Similarly, in Spain, Maestro et al. [55] have proposed an index-based insurance scheme to cover the risk of water supply failure in irrigation districts, which is based on reservoir inflows. However, this proposal is suitable only for water supply systems with low inertia (i.e., where reservoirs can only store enough water to meet users' needs for one year or less), where situations of hydrological drought cannot be forecasted at the beginning of the hydrological year. Nevertheless, this is not the case for most of the river basins in Mediterranean and semiarid developed countries with a high risk of supply gaps, where storage capacity is usually large enough to face long (interannual) drought periods.

The most recent proposal is that developed by Maestro et al. [56] for California, which suggests the use of an index currently calculated by the state's water management authority, aimed at estimating the availability of water in the basin to meet users' demand. The value of this index is calculated in early May every year (at the beginning of the irrigation season), accounting for the value of the same index in the previous year and the forecasted runoff for the current hydrological year. As the value of the index is affected by its own value in the previous year, there is a high risk of intertemporal adverse selection. To minimize this problem, the authors propose three alternative insurance designs: (a) 'early bird' insurance (the product must be bought one year before the irrigation season begins); (b) variable premium insurance; and (c) variable deductible insurance.

Finally, it should be noted that agricultural insurance can also be classified depending on the role of public authorities. If the function of the public sector is purely regulatory and in defense of competition, the agricultural insurance system is private. However, mixed public-private systems are also common. Under these public-private partnerships, agricultural insurance is part of the agricultural policy and the state creates the regulatory framework to promote this risk management instrument through subsidies and public reinsurance. The state is motivated to do so in view of the social benefits derived from its implementation [3,38,39].

\section{Proposal for a Hydrological Drought Index-Based Insurance for Irrigation in Spain}

Under Spanish law, all water resources are in the public domain, and consequently, any private water use (e.g., irrigation or industrial uses) is subject to administrative authorizations or legal concessions (water use rights), which are granted by the River Basin Agencies (RBAs) for extended periods (from 25 to 75 years). However, it is worth differentiating between the volumes set in these concessions or water rights, which theoretically are fixed in order to meet all users' needs, and water effectively delivered to rights holders (e.g., irrigators) each year (water allotments), which depends on the available water stored in reservoirs in the current hydrological year. Thus, the water volume specified in the water rights is only actually available for irrigators in average or wet hydrological years, when total water availability is higher than the aggregated water rights granted. In cases of resource scarcity (hydrological drought years), water resources are prioritized, and domestic water users are served first. For irrigation and other economic uses, the remaining water resources available are allocated proportionally. Thus, irrigators have to deal with interannual variability in their water allotments; they may sometimes receive a much smaller volume than that established in their concessions, and in some years may even receive no allotment at all, generating 'water supply gap' situations. In this regard, a new insurance scheme to cover this type of risk could play a fundamental role in enhancing irrigators' risk management in order to stabilize agricultural incomes. 
The Spanish Agricultural Insurance System (SAIS) is one of the most well-developed and successful systems worldwide [4,15]. The maturity of the SAIS is evidenced by its penetration rates: in 2017, more than 234 thousand agricultural policies were contracted, covering 13.8 million hectares $(36.9 \%$ of the total crop production area), insuring a capital of 9.93 billion Euros $(34.6 \%$ of the total agricultural production value) [57]. Much of the success of the SAIS is due to the reduction in commercial insurance premiums thanks to the subsidies granted by the public sector. This public support averages $40 \%$ of the cost of the policies [57] and, in some insurance lines, reaches up to $65 \%$, the maximum allowed by the European Union. Configured through a public-private partnership [58], the insurance policies offered cover multiple perils in many crop production, including all climatological risks (e.g., hail or frost, and even drought in rainfed crops). However, as previously mentioned, irrigated agriculture remains unprotected against the risk of irrigation water supply gaps.

In this paper, a hydrological drought index-based insurance scheme for irrigated agriculture is proposed as the most suitable insurance design, given the advantages of index-based insurance over traditional insurance, as explained in the previous section. The benefits derived from the lower management and administration costs and greater transparency of this type of insurance outweigh the shortcomings stemming from the basis risk, especially when the index chosen meets the aforementioned requirements.

Another relevant factor justifying the choice of index-based insurance to cover the risk of hydrological drought is related to the procedure followed in Spanish RBAs to set annual water allotments. In Spain, irrigators are represented in the Commissions on Reservoir Water Releases (Comisiones de Desembalse). In April each year (at the beginning of the irrigation season, when reservoirs reach their highest storage levels), the Commissions propose to RBAs the water allotments to be set for the irrigation season. RBAs have traditionally considered these proposals, taking into account the active farmers' lobbying activities. The possibility that the irrigators (potential insured parties) may have influenced the probability of loss occurrence (water allotments lower than water rights) made the risk of water supply gaps uninsurable (supply gaps could be artificially generated).

Nevertheless, since the approval of the Basin Drought Plans (BDPs) in 2007, RBAs' annual water allocation decisions must adhere to the action protocols established for that purpose, at least in theory (in practice, these guidelines have not always been fully implemented). Indeed, BDPs, in accordance with the requirements set by the European Water Framework Directive, have established a technical procedure for the distribution of available water resources based on a system of possible water availability scenarios (normality, pre-alert, alert and emergency), minimizing the previously-existing arbitrariness (allocation decisions swayed by pressure from lobbying groups). However, despite the existence of these action protocols, in cases of water scarcity, there is still a certain degree of arbitrariness in the allocation of water [40]. This means that some doubts remain as to whether water supply gaps in Spanish River Basins are an insurable event. This justifies the design of an index-based insurance scheme relying on a transparent and non-manipulable indicator that is highly correlated with the losses to be insured (actual and accidental supply gaps). In this regard, as stated by Brown and Carriquiry [59], Leiva and Skees [54] and Maestro et al. [56], an appropriate index for hydrological drought insurance for irrigation should be based on the river flow accumulation or, as with the approach adopted in this paper, the stock of water available in reservoirs.

In addition, we propose that this hydrological drought insurance for irrigation should be included in the SAIS, with a level of public support similar to the rest of the agricultural insurance schemes in Spain. The SAIS has effectively addressed the problem of covering systemic risks, such as drought in rainfed crops, using private coinsurance and public reinsurance [58]. Thus, it may be deduced that the risk of water supply gaps in irrigated agriculture could also be covered through a coinsurance pool and a public reinsurance program, guaranteeing the viability of this scheme.

Below, we discuss the elements of the proposed insurance contract, following the guidelines summarized in Table 2. 
Regarding the material elements of the contract, the following design options are proposed:

- Insurable interest: contrary to traditional crop insurance, where crop yields are the insurable interest, the proposed contract considers the full annual water allotment (as established in the water right granted by the RBA) as the interest to be insured. Therefore, it is basically a single-risk insurance policy for the farm, but the insurance policy could also be taken out as a complementary coverage alongside the traditional agricultural insurance schemes, if all crops in the farm are insured. In any case, it is worth remarking that a requirement for insuring this type of risk is that the only resources available to insured farmers are from surface water (allotments set annually by the RBA). If farmers have access to alternative sources of irrigation water (e.g., groundwater-wells—or desalinated resources), they can cope with surface water supply gaps by resorting to other sources, and thus do not need insurance.

- Insured capital (IC): this is the value of the annual full water allotment, constituting the maximum amount of compensation that the insurer would be obliged to pay to the insured in case of extreme hydrological drought. In this regard, it is proposed that this value should be agreed or estimated, on a farm-by-farm basis, as equivalent to the difference between the annual gross margin of the insured farm with full water allotment and the estimated annual gross margin of the same farm under rainfed conditions. These calculations should use data on average gross margins for irrigated and rainfed crops in each irrigation district. Thus, by considering the actual planned crop mix under full irrigation (different for each farm) and the typical crop mix under rainfed conditions (the same for every farm), the value of the annual full water allotment could be estimated for each insured farm.

- Index: this is the variable used to determine the occurrence and intensity of the loss. As mentioned above, the index must meet certain requirements; particularly important features are its close correlation with the insured loss and being non-manipulable. Taking into account these characteristics and the analyzed literature, we suggest using an estimate of the stock of water available in reservoirs $(S W)$ of the water system (reservoir network) that supplies irrigation water to the insured farmer. More precisely, it is proposed that this index should be calculated annually on 1 May as the sum of the water stored in the reservoirs at the end of the previous hydrological year (30 September) plus the inflow accumulation in the reservoirs from the beginning of the hydrological year (1 October) to the following 30 April. Thus, this index could be calculated annually at the beginning of May and, depending on its value, it can be determined whether there is a loss (high probability of supply gap—reduced water allotment) and, if so, the intensity thereof, as discussed below.

- Loss: the occurrence of loss is verified when the value of the $S W$ index is lower than a previously determined threshold $T$ of water stored. $T$ corresponds to the minimum stock of water in reservoirs that would allow the RBA to approve full water allotments. Thus, in order for a loss to be declared, $S W$ must be lower than $T$, since under such circumstances there will probably be restrictions on irrigation allotments and, consequently, a loss incurred by irrigated farms. This loss could be 'partial' (SW lower than $T$, but higher than $L$, with the latter parameter defined as the lowest limit of water stock that allows the RBA to approve non-zero irrigation allotments), or 'total' (SW lower or equal to $L$, which would mean zero annual water allotments for irrigation). Therefore, the declaration of losses (and also the indemnity assessment) could be made at the beginning of the irrigation season, specifically on 1 May, once the value of the $S W$ index has been calculated. 
- Indemnity (I): this is the estimated cash amount equivalent to the value of the damages caused by the loss. As it is an index-based insurance scheme, the calculation of the indemnity would not require in-field damage assessment. It would be calculated automatically, after determining the value of $S W$, as follows:

$$
I=\left\{\begin{array}{ccc}
0 & \text { if } & S W \geq T \\
I C \times(1-D E D) \times f(S W) & \text { if } & T>S W>L \\
I C \times(1-D E D) & \text { if } & S W \leq L
\end{array}\right.
$$

As can be seen, the indemnity (I) depends on the deductible (DED, the percentage of the insured capital that the farmer is responsible for covering) and on the intensity of the loss, quantified by the function $f(S W)$. As already pointed out, according to the indemnity principle, the insurance should only cover the actual damage suffered; under no circumstances should the insured party receive an additional benefit. In this sense, to ensure compliance with this principle, and also in order to lower the cost of the premium, a deductible equal to $30 \%$ of the IC is proposed. Regarding the function measuring the intensity of the loss, it could be assumed to be linear: $f(S W)=(T-S W) /(T-L)$. This simplified way of measuring the intensity of the loss entails the assumption that the marginal value of the water allotment remains constant despite the volume of water allotted (i.e., the value of one cubic meter of irrigation water is the same regardless of the scarcity of the resource). In any case, other more accurate functional forms assuming an increasing marginal value of water could be used alternatively in order to measure the intensity of the loss.

- Premium: an annual policy with an annual premium is proposed.

Table 2. Main features of the proposed hydrological drought index-based insurance in Spain.

\begin{tabular}{|c|c|c|}
\hline Type of Element & Element & Main Feature $^{1}$ \\
\hline \multirow{6}{*}{ Material } & Insurable interest & Annual water allotment \\
\hline & Insured capital (IC) & $\begin{array}{l}\text { Difference between the annual gross margin of the insured } \\
\text { farm with full water allotment and the estimated annual } \\
\text { gross margin under rainfed conditions }\end{array}$ \\
\hline & Index & Stock of water available in reservoirs $(S W)$ \\
\hline & Loss & $S W \leq L$ (total) or $T>S W>L$ (partial) \\
\hline & Indemnity $(I)$ & $\begin{array}{c}0 \text { in case of } S W \geq T \\
I C \times(1-D E D) \times f(S W) \text { in case of } T>S W>L \\
I C \times(1-D E D) \text { in case of } S W \leq L\end{array}$ \\
\hline & Premium & Annual \\
\hline \multirow{2}{*}{ Formal } & Contract term & From 30 September year $n$ to 1 May year $n+1$ \\
\hline & Claim & No need for irrigator to inform insurer about the loss \\
\hline \multirow{3}{*}{ Personal } & Insured & $\begin{array}{l}\text { Individual (irrigators) or collective policies } \\
\text { (irrigators' associations) }\end{array}$ \\
\hline & Insurer & $\begin{array}{l}\text { Private-public insurance company pooling all private } \\
\text { insurance companies involved in the SAIS }\end{array}$ \\
\hline & Reinsurer & Public non-profit reinsurance body \\
\hline
\end{tabular}

${ }^{1} \mathrm{~T}$ : minimum value of $S W$ that allows the River Basin Agency (RBA) to approve full water allotments; L: lowest value of $S W$ that allows the RBA to approve non-zero irrigation allotments; $D E D$ : deductible as a percentage of the insured capital.

With regard to the formal elements of the insurance contract, the following design options are proposed:

- Contract term: we propose that the contract is valid from the formalization of the policy during the pre-established contracting period and the corresponding payment of the annual premium (during 
the month of September every year), to 1 May of the following year, after the calculation of the $S W$ index. However, the policy should be extendable for subsequent annuities. In addition, in order to minimize the existence of intertemporal adverse selection, if a pre-alert, alert or emergency situation occurs during the contracting period (September), only policies taken out in previous years would be eligible for renewal. The inclusion of new insured irrigators or modifications in the insured capital due to changes in the crop patterns would only be possible during the contracting period under normal hydrological conditions.

- Claim: as it is an index-based insurance, the irrigators do not have to inform the insurer about the occurrence of a loss. On 1 May, the value of the $S W$ index is calculated and, if this value is lower than $T$, the compensation to be received by each insured irrigator is automatically determined.

Finally, in relation to the personal elements of the insurance contract, the following options are proposed:

- Insured: this could refer to holders of individual policies (irrigators) or collective policies (irrigators' associations including all farmers operating in the same irrigation district).

- Insurer: following the SAIS procedure, it is proposed that Agroseguro, S.A. (the insurance company pooling all private insurance firms engaged in the SAIS) should be the only insurer (only one type of insurance contract with the same terms will be on offer), although the policies may be marketed by the various private insurance companies pooled within the SAIS.

- Reinsurer: similar to the rest of the agricultural insurance schemes included in the SAIS, we suggest that the proposed scheme be reinsured by the Insurance Compensation Consortium (Consorcio de Compensación de Seguros), a public non-profit reinsurance body.

\section{Illustrative Example}

The explanation of the proposal provided above is now complemented with a quantitative example illustrating how the drought index-based insurance proposed could work in a real-world setting. This example is aimed at further supporting the idea that this kind of insurance would be easily implementable, thereby enhancing the resilience of irrigated agriculture (the impact of droughts could be minimized).

For this purpose, the Guadalquivir River Basin (GRB), located in southern Spain, is taken as a case study. The stock of water available in reservoirs in the GRB at the end of April (index $S W$ proposed above for insurance purposes) has already been modeled by Pérez-Blanco and Gómez [33], who reported that the Weibull distribution is the function that best fits historical data:

$$
\begin{gathered}
f(S W ; \lambda, k)=\frac{k}{\lambda}\left(\frac{S W}{\lambda}\right)^{k-1} e^{-\frac{S W}{\lambda}} \\
F(S W ; \lambda, k)=1-e^{-\frac{S W^{k}}{\lambda}}
\end{gathered}
$$

where, $f(S W)$ and $F(S W)$ are, respectively, the probability density function (PDF) and the cumulative distribution function (CDF) for the water stored in reservoirs $(S W)$ expressed as a percentage of the maximum value in the historical data, $k$ is the shape parameter and $\lambda$ is the scale parameter of the distribution. More specifically, for the sub-basin of Regulación General, this PDF was fitted using the values $k=1.484$ and $\lambda=0.347$, as illustrated in Figure 1.

According to Basin Drought Plans (BDPs), the water storage capacity in reservoirs within the sub-basin of Regulación General is $4718 \mathrm{Mm}^{3}$, although the historical maximum volume of water stored on 30 April is $4546 \mathrm{Mm}^{3}(S W=100 \%)$. Average inflows are $3799 \mathrm{Mm}^{3}$ /year, although there is a large interannual variability (standard deviation $=2808$ ). From this stored water, a demand of $2034 \mathrm{Mm}^{3}$ /year must be met, most of it (94\%) for irrigation purposes (293,762 irrigated hectares using an average of $1909 \mathrm{Mm}^{3}$ annually). Hydrological drought events in this sub-basin are determined on 
the basis of the volume of water stored in reservoirs at the beginning of irrigation season (1 May), using the following thresholds:

1. Normality: volume of water stored greater than $3407 \mathrm{Mm}^{3}(S W>75 \%)$. Under this scenario, no constraints are placed on water allotments for irrigation.

2. Pre-alert: volume of water stored between $3407 \mathrm{Mm}^{3}$ and $2273 \mathrm{Mm}^{3}(75 \%<S W<50 \%)$. Under this scenario, irrigation water allotments are reduced by between $5 \%$ and $30 \%$ compared with the normal scenario.

3. Alert: volume of water stored between $2273 \mathrm{Mm}^{3}$ and $1150 \mathrm{Mm}^{3}(50 \%<S W<25 \%)$. Under this scenario, irrigation water allotments are cut by between $30 \%$ and $70 \%$ compared with the normal scenario.

4. Emergency: volume of water stored less than $1150 \mathrm{Mm}^{3}(\mathrm{SW}<25 \%)$. Under this scenario, irrigation water allotments are less than $30 \%$ of the allotments provided under the normal scenario. Moreover, when $S W$ is lower than $10 \%$, zero water allotments have historically been approved in order to guarantee water supply to households and for other urban demands.

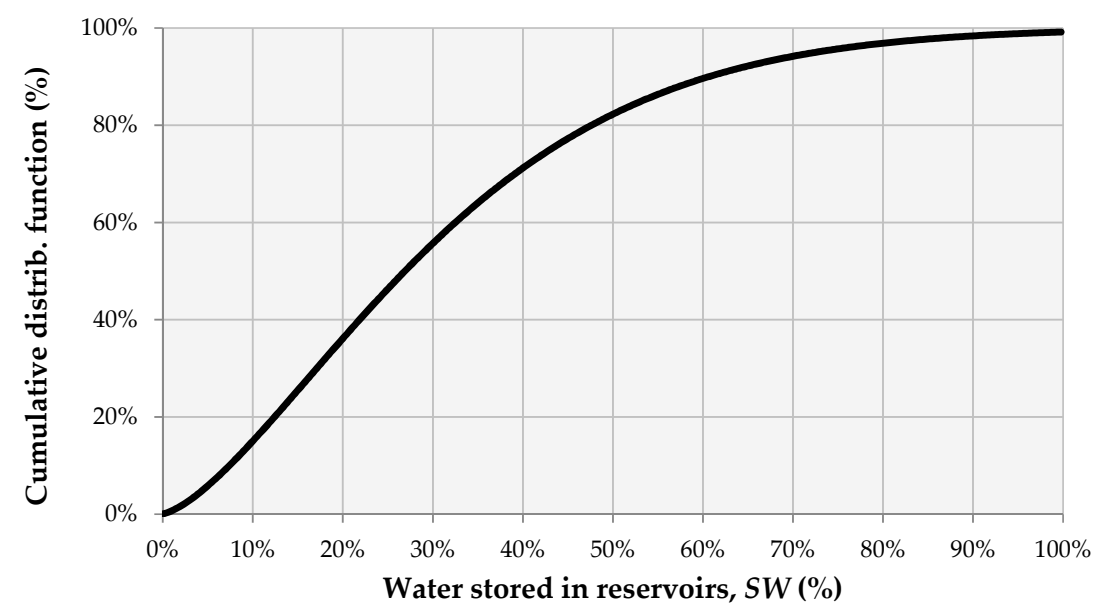

Figure 1. Weibull CDF for water stored in reservoirs in the sub-basin of Regulación General (GRB).

This drought management arrangement means that the minimum stock of water in reservoirs on 30 April that would allow the RBA to approve full water allotments for irrigation ( $T$ ) is $S W_{T}=75 \%$; in cases when $S W<75 \%$ it is expected that these allocations will be cut, which would thus lead to losses in farmers' gross margins. The threshold allowing the RBA to provide non-zero water allotments $(L)$ is $S W_{L}=5 \%$, that is, when $S W<5 \%$ 'total' losses are expected to occur since only rainfed crops could be included in the crop mix.

Under this framework of uncertain irrigation water allotments, consider farmer $X$, who manages an irrigated farm of 50 hectares located in the Genil-Cabra irrigation district, and whose water resources are those provided by the RBA (surface water resources). When full water allotments are provided, he/she opts for the following crop-mix: olive ( $40 \%$ of farm area), cotton $(30 \%)$ and corn (30\%). However, under hydrological drought conditions (water allotments are cut), he/she must change the crop-mix in order to meet irrigation water needs with the water available. In fact, in extreme cases where water allotments are set at zero, he/she must choose a rainfed crop-mix, maintaining olive under rainfed conditions, and substituting irrigated crops with common rainfed options (wheat and sunflower in the case of the Genil-Cabra irrigation district). Table 3 shows the annual gross margin of farm $X$ with full water allotment and under rainfed conditions (zero water allotment) based on average data from this irrigation district [60]. The difference between the two sets of figures ( $783 € /$ hectare, totaling 39,128 Euros for the whole farm area) is an estimate of the value of the annual full water allotment, i.e., the insured capital (IC). Similar assessments could be done for any other farm willing to be insured. 
Consider that farmer $\mathrm{X}$ formalizes the proposed insurance every year during the contracting period (month of September), paying the annual premium set by the insurer. Note that this premium to be paid to the insurer is not fixed in this example since this would require the use of actuarial and financial methods that are beyond the scope of this paper. Thus, the farmer is able to claim an indemnity in the event of losses, calculated according to the value of the index SW on 1 May. In this sense, several scenarios are possible according to expression (1):

- Year $n: S W_{n}=80 \%$. In this case, since $S W_{n}$ is larger than $T$, no losses can be claimed (normal water allocations).

- Year $m: S W_{n}=50 \%$. In this case, since $S W_{m}$ is smaller than $T$, but larger than $L$, the indemnity to be claimed can be calculated as follows: $I=I C \times(1-D E D) \times \frac{T-S W}{T-L}=39,128$ Euros $\times$ $(1-30 \%) \times \frac{75 \%-50 \%}{75 \%-25 \%}=13,695$ Euros.

- Year $p: S W_{p}=20 \%$. In this case, since $S W_{p}$ is smaller than $L$, the indemnity to be claimed equals the insured capital minus the deductible: $I=I C \times(1-D E D)=39,128$ Euros $\times(1-30 \%)=$ 27,390 Euros.

Table 3. Gross margins with full and zero water allotments. Assessment of insured capital (IC) ${ }^{1}$.

\begin{tabular}{cccccc}
\hline \multicolumn{2}{c}{ Full Water Allotment } & \multicolumn{2}{c}{ Zero Water Allotment } \\
\hline Crop & Farm area & Gross margin & Crop & Farm area & Gross margin \\
\hline Olive-irrigated & $40 \%$ & $1003 € /$ hectare & Olive-rainfed & $40 \%$ & $589 € /$ hectare \\
Cotton-irrigated & $30 \%$ & $962 € /$ hectare & Wheat-rainfed & $30 \%$ & $179 € /$ hectare \\
Corn-irrigated & $30 \%$ & $1494 € /$ hectare & Sunflower-rainfed & $30 \%$ & $219 € /$ hectare \\
\hline Whole-farm & $100 \%$ & $1138 € /$ hectare & Whole-farm & $100 \%$ & $355 € /$ hectare \\
\hline \multicolumn{4}{c}{${ }^{1}$ Data obtained from Guerrero-Baena et al. [60] for the Genil-Cabra irrigation district. }
\end{tabular}

Of course, it is true that the indemnities calculated following expression (1) may not be exactly the same as the actual losses suffered by the farmers due to allotment cuts (basis risk), but estimated and actual losses are expected to be similar. In any case, as pointed out earlier in this paper, this is the only drawback of index-based insurance schemes, and it is outweighed by the long list of advantages that reduce the cost of the premiums (e.g., no in-field damage assessment required, no room for conflict between farmers and insurers in indemnity assessment, and moral hazard and adverse selection problems are minimized).

\section{Conclusions}

Due to global change, the failure to guarantee water supply for irrigation is an increasingly pressing risk in Mediterranean-climate regions [61,62]. The severe consequences that hydrological droughts may entail for irrigated agriculture are prompting policy and academic debates about how to effectively manage this type of risk. As supply-side instruments, based on the construction of new water infrastructures, are no longer a viable option in most agricultural regions with mature water economies (i.e., closed basins), the development of new demand-side instruments is needed. In this regard, hydrological drought insurance is a promising instrument for managing the risk of water supply gaps in irrigated agriculture.

In this paper, hydrological drought insurance indexed to the variable 'stock of water available in reservoirs' has been proposed to cover the risk of water supply gaps in irrigated agriculture. This new insurance scheme would be a viable option, since it minimizes many of the problems associated with traditional agricultural insurance, such as adverse selection and moral hazard. It also reduces the cost of the premium because there is no need to make in-field damage evaluations in the event of drought losses. Moreover, the proposed index-based insurance solves certain limitations related to arbitrariness in RBAs' water allotments decision-making. Likewise, the proposed insurance scheme allows this 
strategy to be combined with other risk management instruments, such as spot water markets and water banks.

The implementation of the proposed insurance in a real-life setting requires additional studies from a supply-side perspective, in order to calculate the commercial premium of the insurance scheme using actuarial and financial methods. Also, further studies from the demand perspective are needed to determine the potential acceptance of this risk management instrument by irrigators through their willingness to pay for such an insurance policy. The comparison of the results of supply- and demand-side studies will allow an exploration of the commercial viability of the scheme proposed. If a significant share of irrigators has a willingness to pay greater than the commercial premium, then the insurance would be viable without the need for public subsidies. In any case, there will be a percentage of irrigators whose willingness to pay is lower than the commercial premium and, therefore, their decision will be to not take out the proposed insurance. Obviously, the existence of public subsidies (and thus cheaper premiums) would mean that a higher percentage of irrigators will choose to take out these insurance policies. In light of this situation, it would be worth analyzing the heterogeneity of irrigators' preferences regarding hydrological drought insurance and the impact of public subsidies on the insurance adoption rate. This information would help support efficient policy decision-making regarding this agricultural insurance scheme.

All the studies outlined above indicate the future lines of research to be developed in order to implement this new insurance scheme and, consequently, improve the economic, social and environmental performance of irrigated agriculture while guaranteeing its resilience in the face of global change.

Author Contributions: M.D.G.-B. and J.A.G.-L. contributed equally to the conceptualization, development, writing, and editing of the manuscript.

Funding: The authors acknowledge the financial support from the Spanish Ministry of Science, Innovation and Universities and the European Regional Development Fund (ERDF) through the research project IRRIDROUGHT (AGL2018-48080). These funding institutions had no involvement in the conduct of the research nor the preparation of the paper.

Acknowledgments: The authors are particularly grateful to the anonymous reviewers and the editors for their very helpful comments on previous versions of the paper.

Conflicts of Interest: The authors declare no conflict of interest.

\section{References}

1. Moschini, G.; Hennessy, D.A. Uncertainty, risk aversion, and risk management for agricultural producers. In The Handbook of Agricultural Economics; Gardner, B.L., Rausser, G.C., Eds.; Elsevier Science: Amsterdam, The Netherlands, 2001; pp. 87-153.

2. Hardaker, J.B.; Huirne, R.B.M.; Anderson, J.R.; Lien, G. Coping with Risk in Agriculture; CABI Publishing: Wallingford, UK, 2004.

3. OECD (Organisation for Economic Co-operation and Development). Managing Risk in Agriculture: Policy Assessment and Design; OECD Publishing: Paris, France, 2011.

4. Antón, J.; Kimura, S. Risk Management in Agriculture in Spain; OECD Publishing: Paris, France, 2011.

5. IPCC. Climate Change 2014: Impacts, Adaptation, and Vulnerability. Part A: Global and Sectoral Aspects. Contribution of Working Group II to the Fifth Assessment Report of the Intergovernmental Panel on Climate Change; Cambridge University Press: Cambridge, UK, 2014.

6. Garcia-Ruiz, J.M.; Lopez-Moreno, J.I.; Vicente-Serrano, S.M.; Lasanta-Martinez, T.; Begueria, S. Mediterranean water resources in a global change scenario. Earth-Sci. Rev. 2011, 105, 121-139. [CrossRef]

7. Lehner, B.; Döll, P.; Alcamo, J.; Henrichs, T.; Kaspar, F. Estimating the impact of global change on flood and drought risks in Europe: A continental, integrated analysis. Clim. Chang. 2006, 75, 273-299. [CrossRef]

8. Rigby, D.; Alcón, F.; Burton, M. Supply uncertainty and the economic value of irrigation water. Eur. Rev. Agric. Econ. 2010, 37, 97-117. [CrossRef]

9. Mesa-Jurado, M.A.; Martin-Ortega, J.; Ruto, E.; Berbel, J. The economic value of guaranteed water supply for irrigation under scarcity conditions. Agric. Water Manag. 2012, 113, 10-18. [CrossRef] 
10. Alcón, F.; Tapsuwan, S.; Brouwer, R.; de Miguel, M.D. Adoption of irrigation water policies to guarantee water supply: A choice experiment. Environ. Sci. Policy 2014, 44, 226-236. [CrossRef]

11. Garrido, A.; Gómez-Ramos, A. Risk management instruments supporting drought planning and policy. In Coping with Drought Risk in Agriculture and Water Supply Systems. Drought Management and Policy Development in the Mediterranean; Iglesias, A., Garrote, L., Cancelliere, A., Cubillo, F., Wilhite, D.A., Eds.; Springer: Dordrecht, The Netherlands, 2009; pp. 133-151.

12. OECD (Organisation for Economic Co-operation and Development). Mitigating Droughts and Floods in Agriculture. Policy Lessons and Approaches; OECD Publishing: Paris, France, 2016.

13. Rey, D.; Pérez-Blanco, C.D.; Escriva-Bou, A.; Girard, C.; Veldkamp, T.I.E. Role of economic instruments in water allocation reform: Lessons from Europe. Int. J. Water Resour. D 2018, 1-34. [CrossRef]

14. Howden, S.M.; Soussana, J.-F.; Tubiello, F.N.; Chhetri, N.; Dunlop, M.; Meinke, H. Adapting agriculture to climate change. Proc. Natl. Acad. Sci. USA 2007, 104, 19691-19696. [CrossRef]

15. Meuwissen, M.P.M.; de Mey, Y.; van Asseldonk, M. Prospects for agricultural insurance in Europe. Agric. Financ. Rev. 2018, 78, 174-182. [CrossRef]

16. Menapace, L.; Colson, G.; Raffaelli, R. Risk aversion, subjective beliefs, and farmer risk management strategies. Am. J. Agric. Econ. 2013, 95, 384-389. [CrossRef]

17. Beare, S.C.; Bell, R.; Fisher, B.S. Determining the value of water: The role of risk, infrastructure constraints, and ownership. Am. J. Agric. Econ. 1998, 80, 916-940. [CrossRef]

18. Marques, G.F.; Lund, J.R.; Howitt, R.E. Modeling irrigated agricultural production and water use decisions under water supply uncertainty. Water Resour. Res. 2005, 41, W08423. [CrossRef]

19. Gómez-Limón, J.A.; Picazo-Tadeo, A.J. Irrigated agriculture in Spain: Diagnosis and prescriptions for improved governance. Int. J. Water Resour. D 2012, 28, 57-72. [CrossRef]

20. Guyennon, N.; Salerno, F.; Portoghese, I.; Romano, E. Climate change adaptation in a Mediterranean semi-arid catchment: Testing managed aquifer recharge and increased surface reservoir capacity. Water 2017, 9, 689. [CrossRef]

21. Daccache, A.; Ciurana, J.S.; Rodriguez Diaz, J.A.; Knox, J.W. Water and energy footprint of irrigated agriculture in the Mediterranean region. Environ. Res. Lett. 2014, 9, 124014. [CrossRef]

22. Rey, D.; Garrido, A.; Calatrava-Leyva, J. Comparison of different water supply risk management tools for irrigators: Option contracts and insurance. Environ. Resour. Econ. 2016, 65, 415-439. [CrossRef]

23. EC (European Commission). Communication from the Commission to the European Parliament, the Council, the European Economic and Social Committee and the Committee of the Regions. An EU Strategy on Adaptation to Climate Change; European Commission: Brussels, Belgium, 2013.

24. Varela-Ortega, C.; Blanco-Gutiérrez, I.; Esteve, P.; Bharwani, S.; Fronzek, S.; Downing, T. How can irrigated agriculture adapt to climate change? Insights from the Guadiana Basin in Spain. Reg. Environ. Chang. 2016, 16, 59-70. [CrossRef]

25. EC (European Commission). Communication from the Commission to the European Parliament, the Council, the European Economic and Social Committee and the Committee of the Regions. The Future of Food and Farming; European Commission: Brussels, Belgium, 2017.

26. Molle, F.; Wester, P.; Hirsch, P. River basin closure: Processes, implications and responses. Agric. Water Manag. 2010, 97, 569-577. [CrossRef]

27. Expósito, A.; Berbel, J. Agricultural irrigation water use in a closed basin and the impacts on water productivity: The case of the Guadalquivir river basin (Southern Spain). Water 2017, 9, 136. [CrossRef]

28. Lago, M.; Mysiak, J.; Gómez, C.M.; Delacámara, G.; Maziotis, A. Use of Economic Instruments in Water Policy: Insights from International Experience; Springer: Cham, Switzerland, 2015.

29. Berbel, J.; Gutiérrez-Martín, C.; Rodríguez-Díaz, J.A.; Camacho-Poyato, E.; Montesinos, P. Literature review on rebound effect of water saving measures and analysis of a Spanish case study. Water Resour. Manag. 2015, 29, 663-678. [CrossRef]

30. Debaere, P.; Richter, B.D.; Davis, K.F.; Duvall, M.S.; Gephart, J.A.; O’Bannon, C.E.; Pelnik, C.; Powell, E.M.; Smith, T.W. Water markets as a response to scarcity. Water Policy 2014, 16, 625-649. [CrossRef]

31. Montilla-López, N.M.; Gutiérrez-Martín, C.; Gómez-Limón, J.A. Water banks: What have we learnt from the international experience? Water 2016, 8, 466. [CrossRef]

32. Rey, D.; Calatrava-Leyva, J.; Garrido, A. Optimisation of water procurement decisions in an irrigation district: The role of option contracts. Aust. J. Agric. Resour. Econ. 2016, 60, 130-154. [CrossRef] 
33. Pérez-Blanco, C.D.; Gómez, C.M. Insuring water: A practical risk management option in water-scarce and drought-prone regions? Water Policy 2014, 16, 244-263. [CrossRef]

34. McKee, T.B.; Doesken, N.J.; Kleist, J. The relationship of drought frequency and duration to time scales. In Proceedings of the 8 th Conference on Applied Climatology, Anaheim, CA, USA, 17-22 January 1993; pp. 179-183.

35. Vicente-Serrano, S.M.; Beguería, S.; López-Moreno, J.I. A multiscalar drought index sensitive to global warming: The Standardized Precipitation Evapotranspiration Index. J. Clim. 2010, 23, 1696-1718. [CrossRef]

36. Shafer, B.A.; Dezman, L.E. Development of a surface water supply index (SWSI) to assess the severity of drought conditions in snowpack runoff areas. In Proceedings of the 50 th Annual Western Snow Conference, Colorado State University, Fort Collins, CO, USA, 19-23 April 1982; pp. 164-175.

37. Kao, S.-C.; Govindaraju, R.S. A copula-based joint deficit index for droughts. J. Hydrol. 2010, 380, 121-134. [CrossRef]

38. World Bank. Managing Agricultural Production Risk: Innovations in Developing Countries; World Bank: Washington, DC, USA, 2005.

39. EC (European Commission). Risk Management Schemes in EU Agriculture. Dealing with Risk and Volatility; European Commission: Brussels, Belgium, 2017.

40. Pérez-Blanco, C.D.; Gómez, C.M. Designing optimum insurance schemes to reduce water overexploitation during drought events: A case study of La Campiña, Guadalquivir River Basin, Spain. J. Environ. Econ. Pol. 2013, 2, 1-15. [CrossRef]

41. Pérez-Blanco, C.D.; Delacámara, G.; Gómez, C.M.; Eslamian, S. Crop insurance in drought conditions. In Handbook of Drought and Water Scarcity: Environmental Impacts and Analysis of Drought and Water Scarcity; Eslamian, S., Eslamian, F.A., Eds.; CRC Press: New York, NY, USA, 2017; pp. 423-444.

42. Mishra, A.K.; Wesley Nimon, R.; El-Osta, H.S. Is moral hazard good for the environment? Revenue insurance and chemical input use. J. Environ. Manag. 2005, 74, 11-20. [CrossRef] [PubMed]

43. Just, R.E.; Calvin, L.; Quiggin, J. Adverse selection in crop insurance: Actuarial and asymmetric information incentives. Am. J. Agric. Econ. 1999, 81, 834-849. [CrossRef]

44. Coble, K.H.; Knight, T.O.; Pope, R.D.; Williams, J.R. An expected-indemnity approach to the measurement of moral hazard in crop insurance. Am. J. Agric. Econ. 1997, 79, 216-226. [CrossRef]

45. Goodwin, B.K.; Smith, V.H. An ex post evaluation of the conservation reserve, federal crop insurance, and other government programs: Program participation and soil erosion. J. Agric. Resour. Econ. 2003, 28, 201-216.

46. Skees, J.R.; Barnett, B.J.; Collier, B. Agricultural insurance. Background and context for climate adaptation discussions. In Proceedings of the Prepared for the OECD Expert Workshop on "Economic Aspects of Adaptation", Paris, France, 7-8 April 2008.

47. Herweijer, C.; Ranger, N.; Ward, R.E.T. Adaptation to climate change: Threats and opportunities for the insurance industry. Geneva Pap. Risk Insurance Issues Pract. 2009, 34, 360-380. [CrossRef]

48. Ruiz, J.; Bielza, M.; Garrido, A.; Iglesias, A. Dealing with drought in irrigated agriculture through insurance schemes: An application to an irrigation district in Southern Spain. Span. J. Agric. Res. 2015, 13, e0106. [CrossRef]

49. Bielza, M.; Conte, C.G.; Dittman, C.; Gallego-Pinilla, F.J.; Stroblmair, J. Agricultural Insurance Schemes; Joint Research Centre: Ispra, Italy, 2008.

50. Bielza, M.; Conte, C.G.; Catenaro, R.; Gallego-Pinilla, F.J. Agricultural Insurance Schemes II. Index Insurances; Joint Research Centre, Ed.; Joint Research Centre: Ispra, Italy, 2008.

51. Jensen, N.D.; Barrett, C.B. Agricultural index insurance for development. Appl. Econ. Perspect. Policy 2017, 39, 199-219. [CrossRef]

52. World Bank. Weather Index Insurance for Agriculture: Guidance for Development Practitioners; World Bank: Washington, DC, USA, 2011.

53. Zeuli, K.A.; Skees, J.R. Rainfall insurance: A promising tool for drought management. Int. J. Water Resour. D 2005, 21, 663-675. [CrossRef]

54. Leiva, A.J.; Skees, J.R. Using irrigation insurance to improve water usage of the Rio Mayo Irrigation System in Northwestern Mexico. World Dev. 2008, 36, 2663-2678. [CrossRef]

55. Maestro, T.; Bielza, M.; Garrido, A. Hydrological drought index insurance for irrigation districts in Spain. Span. J. Agric. Res. 2016, 14, e0105. [CrossRef] 
56. Maestro, T.; Barnett, B.J.; Coble, K.H.; Garrido, A.; Bielza, M. Drought index insurance for the Central Valley Project in California. Appl. Econ. Perspect. Policy 2016, 38, 521-545. [CrossRef]

57. Agroseguro, S.A. El Seguro Agrario en Cifras 2017; Agroseguro: Madrid, Spain, 2018.

58. Bardají, I.; Escribano, S.; Garrido, A. Principios Básicos de Seguros Agrarios; Cajamar Caja Rural: Almería, Spain, 2016.

59. Brown, C.; Carriquiry, M. Managing hydroclimatological risk to water supply with option contracts and reservoir index insurance. Water Resour. Res. 2007, 43, W11423. [CrossRef]

60. Guerrero-Baena, M.D.; Villanueva, A.J.; Gómez-Limón, J.A.; Glenk, K. Willingness to pay for improved irrigation water supply reliability: An approach based on probability density functions. Agric. Water Manag. 2019, 217, 11-22. [CrossRef]

61. Iglesias, A.; Garrote, L.; Flores, F.; Moneo, M. Challenges to manage the risk of water scarcity and climate change in the Mediterranean. Water Resour. Manag. 2007, 21, 775-788. [CrossRef]

62. Falloon, P.; Betts, R. Climate impacts on European agriculture and water management in the context of adaptation and mitigation-The importance of an integrated approach. Sci. Total Environ. 2010, 408, 5667-5687. [CrossRef] [PubMed]

(C) 2019 by the authors. Licensee MDPI, Basel, Switzerland. This article is an open access article distributed under the terms and conditions of the Creative Commons Attribution (CC BY) license (http://creativecommons.org/licenses/by/4.0/). 